A N N A LES

UNIVERSITATIS MARIAE CURIE-SKŁODOWSKA

LUBLIN - POLONIA

VOL. LXVI, 1

SECTIO G

2019

Uniwersytet Wrocławski

MACIEJ MARSZAE

maciej.marszal@uwr.edu.pl

ORCID: 0000-0001-7998-5743

\title{
Przyczynek do dyskusji nad faszystowskim prawem gospodarczym
}

A Contribution to the Discussion on Commercial Law of Fascist Italy

Analizy doktryny faszystowskiej i ustroju politycznego wprowadzonego przez Benito Mussoliniego w 1922 r. mają już bogatą tradycję ${ }^{1}$. Należy zaznaczyć, że od początku badań nad tym zjawiskiem pojawiały się istotne trudności interpretacyjne związane z terminem „faszyzm”. Słowo fascio dosłownie znaczy 'wiązka' lub 'pęk'. W starożytnym Rzymie pojęciem tym określano rzemień z toporem noszony przed urzędnikami w celu podkreślenia autorytetu władzy $\mathrm{i}$ jedności państwa. W XIX w. Mariannę, symbol Republiki Francuskiej, często przedstawiano z fasces w ręce, mającymi symbolizować siłę i jedność Republiki wobec jej wrogów z kręgów arystokracji i kleru. Pod koniec ubiegłego stulecia włoscy rewolucjoniści używali terminu fascio, aby wywołać poczucie solidarności we własnych szeregach. Chłopi, którzy w latach 1893-1894 wystąpili na Sycylii przeciwko właścicielom ziemskim, nazywali siebie Fasci Siciliani. W okresie I wojny światowej Mussolini, szukając sposobu na przyłączanie Italii do wojny po stronie aliantów i podkreślenie jedności nacjonalistycznych, a także syndykalistycznych rewolucjonistów, zaczął posługiwać się terminem fascio. Wtedy przyszły Duce nie miał jednak wyłączności na używanie określenia fascio, ponieważ posługiwały się nim również grupy o różnych poglądach politycznych. Jak podaje amerykański badacz Robert Paxton, faszyzm narodził się w sali spotkań Stowarzyszenia Przemysłu i Handlu w Mediolanie w dniu 23 marca 1919 r., na którym około 100 weteranów wojennych, syndykalistów, futurystów i nacjonali-

1 Przy pisaniu artykułu wykorzystano niektóre fragmenty z pracy: M. Marszał, Faszyzm i jego oblicza, [w:] Varia Doctrinalia, red. Ł. Machaj, Wrocław 2012, s. 27-35. 
stów sprzeciwiło się hasłom socjalistycznym i zadeklarowało swój nacjonalizm. Od tego momentu Mussolini nazwał swój ruch Fasci Italiani di Combattimento, co symbolizowało „braterstwo walki”. Początkowo poglądy głoszone przez członków partii faszystowskiej stanowiły mieszaninę nacjonalizmu, socjalizmu, syndykalizmu i populizmu. Dopiero po latach powstała jedna doktryna polityczna faszyzmu, której strażnikiem okazał się Mussolini, uważający się za jej głównego twórcę i ucieleśnienie².

W literaturze naukowej po II wojnie światowej brak jest jednolitej definicji faszyzmu. Jak pisał Walter Laqueur, nazwa „faszyzm” przypomina słowo „pornografia”, ponieważ nie jest terminem wiążącym pod względem prawnym, lecz mimo to każdy, kto ma do czynienia z jednym bądź drugim zjawiskiem, potrafi

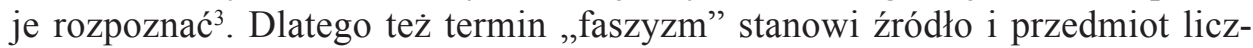
nych interpretacji i polemik. Samo przytoczenie tych - choćby tylko powstałych w sferze naukowej - definicji może stanowić przedmiot osobnej monografii, i to zapewne niejednej. $Z$ tego względu świadomie zrezygnowałem $\mathrm{z}$ umieszczenia w swojej rozprawie rozważań na ten temat, ograniczając się do wskazania definicji faszyzmu występujących w polskich pracach okresu międzywojennego. Znakomity znawca tej problematyki Renzo de Felice wyróżnił aż dziewięć rodzajów interpretacji faszyzmu. Ujmowały one faszyzm jako: chorobę moralną Europy, wynik historycznego rozwoju, wytwór społeczeństwa kapitalistycznego, formę totalitaryzmu, zjawisko transpolityczne. De Felice traktował faszyzm także z punktu widzenia katolickiego, psychospołecznego, socjologicznego i socjoekonomicznego ${ }^{4}$. Natomiast Maria Zmierczak wyróżniła w powojennych badaniach nad faszyzmem pięć ujęć problemu: psychologiczne, którego głównymi przedstawicielami byli Wilhelm Reich, Erich Fromm i Hannah Arendt; fenomenologiczne na czele z Ernstem Noltem; historyczno-socjologiczne, reprezentowane przez Gini Germaniego i Heinricha Augusta Winklera; politologiczno-prawnicze, głoszone m.in. przez Johna Solé Tura i Paula Marlora Sweezy'ego; ekonomiczno-społeczne, wyrażane m.in. przez Karla Dietricha Brachera i Andreasa Hillgrubera 5 .

Włoski faszyzm nie ograniczał się tylko do postulatów politycznych, lecz także podejmował ważne problemy społeczno-gospodarcze. Elementem konstytutywnym włoskiej doktryny był korporacjonizm, który miał decydujący wpływ na kształt włoskiego ustawodawstwa dotyczącego prawa konstytucyjnego, administracyjnego, podatkowego, gospodarczego oraz prawa pracy i ubezpieczeń społecznych. Korporacyjne rozwiązania kreowały stosunek jednostki wobec narodu,

2 R. Paxton, Anatomia faszyzmu, Warszawa 2005, s. 5 i n.

W. Laqueur, Faszyzm. Wczoraj, dziś, jutro, Warszawa 1998, s. 5 i n.

4 R. de Felice, Interpretacje faszyzmu, Warszawa 1978, s. 5 i n.

5 M. Zmierczak, Spory o istotę faszyzmu. Dzieje i praktyka, Warszawa-Poznań 1988, s. 3 i n. 
obywatela wobec państwa. Faszystowski program gospodarczo-społeczny stanowił z jednej strony zaprzeczenie liberalnej gospodarki wolnorynkowej, a z drugiej był przeciwwagą dla zdobywającej poklask społeczny ideologii walki klas głoszonej przez socjalistów i komunistów. Idea faszystowskiego korporacjonizmu we Włoszech dawała wizję pokoju społecznego, ukazywała perspektywę usprawnienia państwa przez podporządkowanie związków zawodowych państwu oraz thumiła podziały społeczne na linii pracodawca - pracownik.

Należy zaznaczyć, że od chwili narodzin faszyzmu i mowy Mussoliniego w 1919 r. wygłoszonej na Piazza san Sepolcro, głosił on bezustannie o „korporacji” i zalecał hufcom bojowym przyjęcie na swój rachunek sprawy narodowego syndykalizmu. Prawie wszyscy rewolucjoniści, którzy opowiedzieli się w czasie wojny za interwencją Włoch, należeli do Włoskiej Unii Pracy, której przewodniczył sekretarz Izby Bolońskiej i organizator emigracji włoskiej w Stanach Zjednoczonych - Edmondo Rossini. Organizacja ta konkurowała z socjalistyczną Konfederacją Generalną i osiągała rezultaty. Warto tu wspomnieć o akcji bezpośredniej z marca 1919 r., polegającej na okupacji zakładów Franco-Gregorini w Dalminie ${ }^{6}$. $\mathrm{Na}$ bazie hufców bojowych zaczęły powstawać pierwsze syndykaty faszystowskie, które przybrały nazwę „korporacji”. Jeszcze przed „marszem na Rzym”, bo w dniach 24-25 stycznia 1922 r., w Bolonii odbył się pierwszy kongres syndykalistów włoskich, na którym określono zasady korporacjonizmu. Wtedy też Rossoni Grandi i Michele Blanchi stworzyli w Bolonii Federacyjną Unię Korporacyjną, która wkrótce przybrała nazwę Konfederacji Faszystowskich Korporacji Syndykalistycznych. Korporacji było początkowo sześć, później liczba ich wzrosła do czternastu. Do głównych twórców faszystowskiego korporacjonizmu należy zaliczyć Alfreda Rocco, który już w 1914 r. w Mediolanie wyłożył zespół poglądów na temat gospodarki syndykalno-narodowej, oraz Gabriela D'Annunzio - twórcę ustroju korporacyjno-stanowego ${ }^{7}$.

Korporacje stanowiły wprawdzie raczej odgałęzienie partii faszystowskiej niż prawdziwy ruch zawodowy, niemniej zachowały oblicze i charakter zrzeszeń syndykalistycznych. Po podpisaniu układów w Palazzo Vidoni (21 grudnia 1923 r.) i w Palazzio Chigi (2 października 1925 r.) przyznano korporacjom monopol na reprezentację robotników.

Znaczącą zapowiedzią korporacyjnego zorganizowania włoskiego życia gospodarczego był układ z dnia 2 października 1925 r. zawarty w Rzymie przez Konfederację Korporacji Faszystowskich, w którym organizacje pracowników i pracodawców przemysłowych uznały wzajemne prawa do

6 «Revue des études coopératives »1933, $\mathrm{n}^{\circ} 10-12, \mathrm{~s} .53$.

W. Kozub-Ciembroniewicz, Korporacjonizm Wtoch faszystowskich a idee korporacyjne encykliki Quadragesimo Anno, „Studia nad Faszyzmem i Zbrodniami Hitlerowskimi” 1985, nr 9, s. 128. 
reprezentacji swoich zawodów ${ }^{8}$. Dopiero ustawa z dnia 3 kwietnia 1926 r. o prawnym uregulowaniu zbiorowych stosunków pracy (Legge sulla disciplina giuridica dei rapporti collettivi del lavoro ${ }^{9}$ zmieniła kształt i oblicze faszystowskich korporacji. Wiodące znaczenie w tym zakresie miał także dekret królewski z dnia 1 lipca 1926 r. pn. Przepisy dotyczące wprowadzenia w życie prawa z dnia 3 kwietnia 1926 r. n. 563, o prawnym uregulowaniu zbiorowych stosunków pracy ${ }^{10}$.

Ustawy te nadały korporacjom osobowość prawną i publiczną oraz wyposażyły je w prerogatywy administracji państwowej. W efekcie tych zmian korporacje posiadały monopol w kształtowaniu warunków pracy przez zawieranie z pracownikami zbiorowych umów pracy. W świetle faszystowskiego korporacyjnego prawa syndykaty podlegały ścisłej kontroli władz publicznych, które mogły odmówić zatwierdzenia kierownika zrzeszenia, a także mogły mianować czasowy zarząd komisaryczny. Państwo posiadało uprawnienie do ingerowania w uchwały władz syndykatu poprzez uchylanie uchwał sprzecznych z prawem lub statutem. Władze państwowe, wprowadzając totalne rozwiązania ustrojowe, narzuciły włoskim robotnikom własne kadry i doktrynę. I tak sam Mussolini w maju 1926 r. osobiście objął kierownictwo nad nowym resortem - Ministerstwem Korporacji. Jak zauważył Rocco (jeden z twórców włoskiego korporacjonizmu), odrzucenie bezpośredniego stosunku jednostki do państwa i wprowadzenie syndykatów jako ogniwa pośredniego sprawiło, że państwo zostało oparte nie na ,atomistycznym indywidualizmie filozofii francuskiej, lecz na podstawie organicznego rozumienia społeczeństwa"11.

Konsekwencją przemian gospodarczych w faszystowskich Włoszech były zmiany w prawie i sądownictwie pracy, które znalazły swój wyraz w dwóch ustawach: z dnia 3 kwietnia 1926 r. o unormowaniu prawnym zbiorowych stosunków pracy i z dnia 26 lutego 1928 r. powołującej do życia i regulującej działanie trybunałów pracy. Ustawy te ustanawiały trybunały pracy (La Magistratura del Lavoro) mające na celu załatwienie sporów wynikających ze zbiorowych układów pracy. Ponadto posiadały one kompetencję sądu odwoławczego jako sądu II instancji dla rozstrzygania sporów indywidualnych, które rozstrzygane były w I instancji przez wydziały pracy przy sądach zwykłych. Ustawa z dnia 26 lutego 1928 r. dokonała ostatecznej unifikacji sądownictwa pracy tym, że zniesiono instytucję sędziów i organy sądownicze specjalne dla rozstrzygania zatargów pracy i przekazano je kompetencji pretur i trybunałów (sądy pokoju i sądy okręgowe), przy których stworzono osobne wydziały pracy. Od ich orzeczeń można było wnieść odwołanie do trybunału pracy (tzw. Magistratura del Lavoro), istniejącego przy każdym sądzie

8 A. Rocco, La trasformazione dello Stato, Roma 1927, s. 107.

9 Norme per l'attuazionne Della legge 3 aprile, N. 563, sulla disciplina giurdica dei rapporti collettivi del lavoro, „Gazzetta Ufficiale”, 14.04.1926, No. 87.

10 A.M. Corvi, Ustrój faszystowski w Italii, Warszawa 1930, s. 5 i n.

11 A. Rocco, op. cit., s. 22. 
apelacyjnym. Zarówno w sporach wynikłych na tle stosowania umów zbiorowych, jak i wytoczonych przez jednostki przysługiwało odwołanie do Sądu Najwyższego (Corte di Cassazione). Spod kompetencji sądownictwa pracy zostały wykluczone sprawy dotyczące urzędników państwowych i pracowników samorządowych ${ }^{12}$. Należy zaznaczyć, że novum faszystowskiego prawa pracy był fakt, że zakazano wszelkiego rodzaju strajków i lokautów. Pracodawca, który bez uzasadnionej przyczyny dopuścił się do masowych zwolnień pracowników, był narażony na sankcję określoną w prawie karnym w wysokości 100 tys. lirów grzywny. Natomiast pracownicy lub urzędnicy, którzy z własnej winy zaprzestali pracy, podlegali grzywnie w wysokości od 100 do 1000 lirów lub karze więzienia od roku do 2 lat.

Należy szczególnie podkreślić, że według art. 22 ustawy z dnia 3 kwietnia 1926 r. pracodawcy i pracownicy, oprócz odpowiedzialności cywilnej za niewykonywanie wyroków sądów pracy, byli narażeni na sankcję karną pozbawienia wolności na okres od 1 miesiąca do roku oraz grzywnę od 100 do 5000 lirów. Z kolei przedstawiciele osób prawnych, którzy odmówili podania wyroków pracy, byli skazani na karę więzienia od 6 miesięcy do 2 lat oraz grzywnę od 2000 do 10 tys. lirów, jak również byli zobowiązani do złożenia swojego urzędu. Ponadto pracownicy i pracodawcy ponosili odpowiedzialność cywilną za niewykonanie zawartych zobowiązań wobec stowarzyszeń pracowniczych i pracodawczych. Tymczasem stowarzyszenia nie zawierały umów we własnym imieniu, lecz dla pracodawcy i robotnika zsyndykalizowanego. Odpowiedzialność za niewykonanie zobowiązań przez osoby związane umową ponosiły stowarzyszenia jedynie w wypadkach, gdy nie wykazały należytej staranności w wykonaniu umowy ${ }^{13}$.

W wypadkach, kiedy spór o pracę zakłócał porządek kolektywny lub indywidualny, taki konflikt był w pierwszym etapie rozstrzygany przez miejscowy komitet międzysyndykalny, który składał się z pracowników i pracodawców pokrewnej branży. W posiedzeniu brał udział prefekt jako przedstawiciel władzy administracyjnej, reprezentujący państwo, którego celem było załagodzenie sporu pracowniczego. Główną rolę odgrywała jednak partia faszystowska, która była wyrazicielką ,pokoju społecznego” w ramach ustroju faszystowskiego. Jeśli polubowna próba rozstrzygnięcia sporu nie przynosiła rezultatu, strony poddawały się syndykatom wyższego rzędu, syndykatom regionalnym. Jeżeli w drugim postępowaniu nie doszło do ugody, sprawę przejmowała federacja narodowa w Rzymie, gdzie dochodziło do ewentualnego porozumienia między kierownictwem pracodawców i robotników danej gałęzi produkcji. Jeśli ta próba nie przynosiła polubownego rezultatu, to sprawę przejmowało Ministerstwo Korporacji, którego minister osobiście starał się załagodzić spór. W przypadku fiaska w dojściu do

12 T. Chromecki, Autorytarne państwo korporacyjne Mussoliniego, Warszawa 1938, s. 77. Por. Diritto economia e istituzioni nell'Italia fascista, Baden-Baden 2002, s. 5 i n.

13 A.M. Corvi, op. cit., s. 223. 
społecznego porozumienia sprawę przejmował sąd pracy, który wydawał wyrok na podstawie Magistratura del Lavoro ${ }^{14}$.

Sprawy sporne przewidziane w art. 13 ustawy syndykalistycznej z dnia 3 kwietnia 1926 r. w zakresie regulowania zbiorowych stosunków pracy dotyczących bądź wykonania umów zbiorowych i innych istniejących przepisów, bądź żądania nowych warunków pracy, należały do sądów apelacyjnych działających jako sądy pracy. Sądownictwo, którego zadaniem było przestrzeganie wykonywania aktów pracy, miało szeroki zakres władzy, ponieważ sędzia dysponował swoistego rodzaju dowolnością w kształtowaniu stosunków pracy, mógł też konstruować i zmieniać normy z udziałem czynnika społecznego. Przy każdym sądzie apelacyjnym była ułożona lista obywateli biegłych w sprawach produkcji i pracy, podzielona na grupy i podgrupy w zależności od różnego rodzaju przedsiębiorstw leżących na terytorium danego sądu. Lista podlegała rewizji co 2 lata. Przy każdym z 16 sądów apelacyjnych tworzono osobną sekcję złożoną z trzech sędziów, z których jeden był prezesem sekcji, a dwaj pozostali byli radcami sądu apelacyjnego. W każdej sprawie prezes sądu apelacyjnego wyznaczał dwóch obywateli biegłych w zakresie spraw produkcji i pracy.

Należy podkreślić, że sądy apelacyjne przy wskazywaniu nowych warunków pracy kierowały się zasadą słuszności, uwzględniając interes pracowników i pracodawców oraz mając na względzie interesy dobra produkcji. Wyrok sądu pracy zapadał po konsultacji i wysłuchaniu prokuratora.

Na podstawie exposé Ministra Sprawiedliwości Pietro De Francisci ze stycznia 1934 r. oraz ustawy syndykalistycznej z dnia 3 kwietnia 1926 r. i dekretu królewskiego z dnia 26 lutego 1928 r. o sporach indywidualnych w latach 1926-1933 rozstrzygnięto 497 sporów zbiorowych, w tym 364 przemysłowe, 74 rolnicze, 26 handlowych, 20 transportowych, 18 bankowych i 13 dotyczących robotników portowych. Sądy pracy rozstrzygnęły 135908 spraw dotyczących sporów indywidualnych o pracę. Natomiast w latach 1927-1937 Ministerstwo Korporacji rozstrzygnęło 954 konflikty zbiorowe ${ }^{15}$.

Należy zaznaczyć, że faszystowskie ustawodawstwo w zakresie rozstrzygania sporów zbiorowych między pracodawcą a pracownikiem starało się rozwiązać odwieczny dylemat między kapitałem a pracą ${ }^{16}$. Realizowana przez Mussoliniego idea „sprawiedliwości socjalnej” znajdowała swój wyraz w syndykalistyczno-korporacyjnym państwie ${ }^{17}$.

14 G. Zanobini, Corso di diritto corporativo, Roma 1937, s. 314-375.

15 T. Chromecki, op. cit., s. 83-84.

16 M. Marszał, Interpretacje włoskiego faszyzmu w polskiej myśli politycznej i prawniczej 1922-1926, [w:] Doktryny polityczne i prawne u progu XXI wieku, red. M. Maciejewski, M. Marszał, Wrocław 2002, s. 85-91.

17 S. Sierpowski, Faszyzm we Włoszech 1919-1926, Wrocław 1976, s. 243-247. Zob. także: R. Eatwell, Faszyzm. Historia, Poznań 1999, s. 85-137; J. Borejsza, Szkoły nienawiści. Historia faszyzmów europejskich 1919-1945, Wrocław-Warszawa-Kraków 2000, s. 51-63. 
Zupełnie nowym elementem w systemie prawnym faszystowskich Włoch, a zwłaszcza regulacji dotyczących stosunku pracy, była tzw. Karta Pracy (Carta del Lavoro) uchwalona 30 kwietnia $1927 \mathrm{r} .{ }^{18}$ W Karcie Pracy ustawodawca zawarł najwyższe zasady faszyzmu, według których najważniejsza wartość to państwo, któremu jednostka powinna być całkowicie podległa. Już art. 1 Karty Pracy można uznać za manifest uniwersalizmu nad indywidualizmem: „, „... naród italski jest organizmem mającym cele i sposoby działania wyższe niż jednostka i zrzeszenia, które nań się składają. Jest on jednością duchową, polityczną i gospodarczą, która się urzeczywistnia całkowicie w Państwie" ${ }^{\text {"19 }}$. We włoskim faszyzmie praca we wszystkich formach była uznawana za obowiązek społeczny oraz źródło dobrobytu potęgi narodów. Carta del Lavoro, uznając pracę za zasadniczy obowiązek społeczny, traktowała ją jako podstawę budowy ustroju społeczno-gospodarczego ${ }^{20}$. Faszyzm przyznawał decydujące znaczenie jednostce jako wytwórcy - jednostce, która była reprezentantem określonego zawodu. Dlatego też w świetle art. 2 „Praca we wszelkiej postaci - organizacyjnej i wykonawczej, intelektualnej, technicznej, fizycznej - jest obowiązkiem społecznym. $Z$ tego i wyłącznie z tego tytułu pozostaje ona pod ochroną Państwa"21. Zdaniem jednego z teoretyków faszystowskiego prawa, Carlo Costamagny, w korporacyjnym rozumieniu pracy znajdował się pierwiastek ,zbiorowości politycznej”, będącej przeciwnym pojęciem do „grupy partykularnej”. Costamagna thumaczył, że np. ,interes rolnictwa” nie był taki sam, jak interes osób zajmujących się w danym czasie rolnictwem; otóż obejmował on też tych, którzy mieli zajmować się rolnictwem w przyszłości, nie mógł być ograniczony do jakiejś grupy rolniczej. Interesy wielu kategorii zazębiały się i dopełniały wzajemnie tak, jak interes rolnictwa, bez brania pod uwagę handlu czy przemysłu. Łączyły się one ogólnymi warunkami pozaekonomicznymi w jednej kategorii, jaką było państwo ${ }^{22}$.

Kolejnym etapem reformowania faszystowskiego prawa gospodarczego była ustawa z dnia 20 marca 1930 r. o reformie Rady Narodowej Korporacji. We Włoszech powstała zmodyfikowana agenda rządowa, która podlegała bezpośrednio szefowi rządu. W świetle tej ustawy Rada nie posiadała osobowości prawnej, lecz była częścią prawa publicznego (korporacyjnego), miała ona możliwość wydawania niektórych norm ogólnie obowiązujących oraz rozstrzygania sporów między poszczególnymi syndykatami ${ }^{23}$. Ponadto w dniu 19 stycznia 1938 r. w miejsce

18 Carta del Lavoro, „Gazzetta Ufficiale”, 21.04.1927, No. 100.

19 Cyt. za: A.M. Corvi, op. cit., s. 91-92.

20 V. Feroci, Diritto sindacale e corporativo, Milano 1934, s. 50.

21 Carta del Lavoro, „Gazzetta Ufficiale”, 21.04.1927, No. 100.

22 C. Costamagna, Elementi di diritto pubblico fascista, Torino 1938, s. 69.

23 W. Krzyżanowski, Polityka ekonomiczna faszyzmu, Lublin 1933, s. 93-100. Zob. także: G. Bottai, Państwo korporacyjne w stużbie państwa-narodu, „Przegląd Współczesny” 1930, nr 100 101, s. 41-49; J.A. Gierowski, Historia Włoch, Wrocław 1986, s. 513-517; Doktryny polityczne XIX i XX wieku, red. K. Chojnicka, W. Kozub-Ciembroniewicz, Kraków 2000, s. 351-353. 
parlamentu została utworzona Izba Faszystowsko-Korporacyjna, która zorganizowała całościowy aparat faszystowskiego korporacjonizmu, symbolizujący model planowej gospodarki i branżowo-społecznej reprezentacji ${ }^{24}$.

Podsumowując faszystowskie rozwiązania prawne dotyczące kwestii gospodarczych, należy stwierdzić, że miały one oryginalny charakter i służyły politycznym celom wodza faszystowskich Włoch - Mussoliniego. Warto zwrócić uwagę na fakt, że faszystowskie koncepcje prawa gospodarczego rodziły się równolegle z powstawaniem doktryny faszyzmu w 1919 r. Idea korporacyjne, które przyświecały ideologom włoskiego faszyzmu, znalazły swój kompletny wyraz w systemie prawnym wodzowskiego państwa Mussoliniego.

\section{BIBLIOGRAFIA}

Borejsza J., Szkoły nienawiści. Historia faszyzmów europejskich 1919-1945, Wrocław-WarszawaKraków 2000.

Bottai G., Państwo korporacyjne w slużbie państwa-narodu, „Przegląd Współczesny” 1930, nr 100-101.

Carta del Lavoro, „Gazzetta Ufficiale”, 21.04.1927, No. 100.

Chromecki T., Autorytarne państwo korporacyjne Mussoliniego, Warszawa 1938.

Corvi A.M., Ustrój faszystowski w Italii, Warszawa 1930.

Costamagna C., Elementi di diritto pubblico fascista, Torino 1938.

Diritto economia e istituzioni nell'Italia fascista, Baden-Baden 2002.

Doktryny polityczne XIX i XX wieku, red. K. Chojnicka, W. Kozub-Ciembroniewicz, Kraków 2000.

Eatwell R., Faszyzm. Historia, Poznań 1999.

Felice R. de, Interpretacje faszyzmu, Warszawa 1978.

Feroci V., Diritto sindacale e corporativo, Milano 1934.

Gierowski J.A., Historia Włoch, Wrocław 1986.

Kozub-Ciembroniewicz W., Korporacjonizm Włoch faszystowskich a idee korporacyjne encykliki

Quadragesimo Anno, „Studia nad Faszyzmem i Zbrodniami Hitlerowskimi” 1985, nr 9.

Krzyżanowski A., Demograficzne oblicze kryzysu, Kraków 1932.

Krzyżanowski A., Polityka i gospodarstwo, Kraków 1931.

Krzyżanowski A., Rządy Marszałka Pitsudskiego, Kraków 1928.

Krzyżanowski A., Wiek XX. Zarys dziejów najnowszych, Kraków 1947.

Krzyżanowski W., Polityka ekonomiczna faszyzmu, Lublin 1933.

Laqueur W., Faszyzm. Wczoraj, dziś, jutro, Warszawa 1998.

Marszał M., Faszyzm i jego oblicza, [w:] Varia Doctrinalia, red. Ł. Machaj, Wrocław 2012.

Marszał M., Interpretacje włoskiego faszyzmu w polskiej myśli politycznej i prawniczej 1922-1926,

[w:] Doktryny polityczne i prawne u progu XXI wieku, red. M. Maciejewski, M. Marszał, Wrocław 2002.

Norme per l'attuazionne Della legge 3 aprile, N. 563, sulla disciplina giurdica dei rapporti collettivi del lavoro, „Gazzetta Ufficiale”, 14.04.1926, No. 87.

Paxton R., Anatomia faszyzmu, Warszawa 2005.

${ }^{24}$ Doktryny polityczne..., s. 353. Zob. także: A. Krzyżanowski, Polityka i gospodarstwo, Kraków 1931, s. 272-482; idem, Demograficzne oblicze kryzysu, Kraków 1932, s. 3-18; idem, Wiek XX. Zarys dziejów najnowszych, Kraków 1947, s. 63-216; idem, Rząy Marszałka Pitsudskiego, Kraków 1928, s. 11-153. 
« Revue des études coopératives »1933, n 10-12.

Rocco A., La trasformazione dello Stato, Roma 1927.

Sierpowski S., Faszyzm we Włoszech 1919-1926, Wrocław 1976.

Zanobini G., Corso di diritto corporativo, Roma 1937.

Zmierczak M., Spory o istotę faszyzmu. Dzieje i praktyka, Warszawa-Poznań 1988.

\section{SUMMARY}

Italian fascism was not limited only to political issues, but it also covered important socio-economic problems. The basic element of Italian political doctrine was corporatism, which had a decisive influence on the shape of Italian legislation process in the field of constitutional, administrative, tax, commercial, labor and social security law. Corporate solutions created relations of the individual towards nation and citizen towards the state. From one point of view, the fascist socio-economical program denied the liberal free trade economy, but from the other, it was a counterbalance for a developing social ideology of class conflict, which was proclaimed by the socialists and communists. The idea of fascist corporatism in Italy gave a vision of social peace. It also improved the functioning of the government by subordination of trade unions to the state and by suppressing social divisions on the employer - employee line. The purpose of this study was to present fascist commercial law and it's importance for economic policy of Mussolini state. The basic legal acts from the period of 1922 till 1939, which are related to fascist economy, were analyzed.

Keywords: law; fascism; economy; Italy; corporatism

\section{STRESZCZENIE}

Włoski faszyzm nie ograniczał się tylko do postulatów politycznych, lecz także podejmował ważne problemy społeczno-gospodarcze. Elementem konstytutywnym włoskiej doktryny był korporacjonizm, który miał decydujący wpływ na kształt włoskiego ustawodawstwa dotyczącego prawa konstytucyjnego, administracyjnego, podatkowego, gospodarczego, a także prawa pracy i ubezpieczeń społecznych. Korporacyjne rozwiązania kreowały stosunek jednostki wobec narodu, obywatela wobec państwa. Faszystowski program gospodarczo-społeczny stanowił z jednej strony zaprzeczenie liberalnej gospodarki wolnorynkowej, a z drugiej przeciwwagę dla zdobywającej poklask społeczny ideologii walki klas głoszonej przez socjalistów i komunistów. Idea faszystowskiego korporacjonizmu we Włoszech dawała wizję pokoju społecznego i perspektywę usprawnienia państwa przez podporządkowanie związków zawodowych państwu oraz thumiła podziały społeczne na linii pracodawca - pracownik. Przedmiotem artykułu było przedstawienie faszystowskiego ustawodawstwa gospodarczego i jego znaczenia dla polityki ekonomicznej państwa Mussoliniego. Przeanalizowano podstawowe akty prawne z lat 1922-1939 dotyczące faszystowskiej gospodarki.

Słowa kluczowe: prawo; faszyzm; gospodarka; Italia; korporacjonizm 